\title{
Assessment of Phenotypic Diversity in Breeding Lines of Barley at Rampur, Chitwan
}

\author{
Pabitra Ale ${ }^{1, *}$, Aakash Adhikari ${ }^{2}$, Babita Dhungana ${ }^{1}$, Jigyasha Gautam $^{1}$, Anup Adhikari ${ }^{1}$, \\ Krishna Hari Dhakal ${ }^{3}$
}

\author{
${ }^{1}$ Nepal Polytechnic Institute \\ ${ }^{2}$ Himalayan College of Agricultural Sciences and Technologies \\ ${ }^{3}$ Agriculture and Forestry University \\ *Corresponding author: pabitraale99@gmail.com
}

Received: 13 Oct 2021; Received in revised form: 14 Dec 2021; Accepted: 22 Dec 2021; Available online: 31 Dec 2021 C2021 The Author(s). Published by Infogain Publication. This is an open access article under the CC BY license (https://creativecommons.org/licenses/by/4.0/).

\begin{abstract}
The experiment was conducted during winter at the research field of National Maize Research Program (NMRP), Rampur, Chitwan situated in the inner-terai region of Nepal. Field experiment was conducted in the Completely Randomized Block Design (CRBD) with three replications. Three blocks was made on the field as local control to obtain more accurate data. Each block contains 14 experimental units. The collected data was recorded, entered and tabulated in Microsoft Excel and then analyzed by using R-software. Analysis showed non-significant variation for number of heads per meter square and significant variation for all other remaining traits. CHZ-NP-108-OY (111DAS) showed highest days to maturity and B86019-1K-2K-0K3 showed lowest. Days to booting, heading and anthesis were found highest in variety Bonus (std. check) with 81 DAS, 88 DAS and 98 DAS, respectively. Likewise, total quantity of tillers and number of effective tillers were highest in variety B90K-090-0K (2.9 and 2.4 respectively) and lowest in B86019-1K-2K-0K3 (1.9) and B86099-50K (1.6) respectively. Plant height was highest in variety B90K-024-1-1-2-0K (107cm) and lowest in Xveola-15 (82cm). Xveola-38 showed highest result for seed length $(11.2 \mathrm{~mm})$ and grain yield $(1634 \mathrm{~kg} / \mathrm{ha})$. Correlation between most of the traits was significant. Plant height changed into vast and undoubtedly correlated with tiller range $(0.3 *)$, powerful tiller (0.44***), flag leaf width $\left(0.41^{* * *}\right)$ flag leaf period $\left(0.35^{* *}\right)$. Grain yield in keeping with hectare changed into significantly and definitely correlated with days to maturity $\left(0.07^{* *}\right)$, flag leaf width $\left(0.41^{* *}\right)$ plant peak $\left(0.45^{* *}\right)$ and grain yield according to spike (0.1**). B86019-1K-2K-0K3 showed better adaptability and results for phenotypic characters whereas Xveola-38 performed best for the yield and yield attributing traits. So these varieties have the possibilities and potential for further study in Rampur, Chitwan.
\end{abstract}

Keywords - Significant, Correlated, Yield and Non-significant.

\section{INTRODUCTION}

Barley is a short seasoned, early maturing annual grain crop with some degree of tolerance to drought and salinity, which allows its production in a wide range of climatic zones including both irrigated and dry land production areas (Baniya, 1989). The genetic system of the crop is simple; however the species are genetically diverse (Vitrakoti et al., 2016).Barley is cultivated in extensive variety of environments in Nepal(Baniya et al., 1997).It has the capability to evolve well in adverse climatic and stress conditions and moreover, can be managed with little input. The geographical diversification of Nepal including fertile plains, sub-alpine forest hills and the Himalayas serves for the disproportionately large biodiversification, relative to its size. There are different varieties of the barley suiting different agro-climatic 
condition. The diversity assessment of barley helps to choose high-yielding, well adapted varieties to a particular region.

Barley occupies fourth position worldwide with the production of 141423028 tones and fifth in Nepal with production of 30510 tones (FAO, 2018). The total land under barley cultivation in Nepal is 24648ha (Krishi Diary, 2076). The significance of barley as a meals crop will increase with ascending altitude toward the North, wherein other cereals can't be cultivated correctly because of poor edaphic factors and excessive environmental stress, especially drought(OGTR, 2008). Although having so much potential, not many study and research have been conducted on barley as it's far taken as underutilized vegetation. although suggested barley manufacturing within the terai has declined in the past decade from 6000 to 3000 tons in keeping with year, manufacturing in the hills over the equal length has multiplied from 9000 to twelve, 000 tons and from 8000 to 10,000 tons in the mountains(Baniya, 1989). This popularity in hills and mountains may have resulted due to its early maturing ability ( 1 month) before wheat favoring the summer crops. Also, the low adaptability of local varieties and fewer introductions of improved varieties may have caused the decreased production in terai. The research and studies made are limited. Barley has its growing popularity worldwide.

Huge topographical and agro-climatic diversification inside the country does not favor a single variety within all ecological niches. The cultivation and production of barley is low in the terai region due to the less knowledge on suitable lines in the tropical climate. Limited research and study works is major problem regarding the assessment of diversity of this crop. And hence, it calls for a need to study the performance of different varieties in different agro-climatic conditions and assigned the best breeding lines for particular climate type. This research is significant as assessing the high yielding breeding lines in accordance with the ecological diversity is the only way to improve the production and productivity of the marginalized farmers. Also, the availability of the scientific literature is limited because this crop has not been given much importance and is less researched. Moreover, the high yielding varieties of barley are assessed for temperate regions and less significant study has been made for the tropics. This research provides detailed estimates of agro-morphological and phenotypic diversity of available lines for pre-breeding purpose and functional diversity. despite its top notch capacity and possibilities, the crop has no longer been able

to engross pleasant attention concerning studies and impro vement in Nepal and remains underutilized and ignored (Yadav et al., 2018).

\section{MATERIALS AND METHODS}

Available breeding lines of barley at NARC were characterized and assessed for different traits. The experiment became conducted at some point of winter season at the studies subject of national Maize research program (NMRP), Rampur, Chitwan located within the inner-terai vicinity of Nepal from December, 2019 to April, 2020. Area test was conducted within the completely Randomized Block design (CRBD) with 3 replications, each containing 14 experimental units. 14 treatments were assigned randomly into each experimental units. The barley lines were allotted into treatments as below:

Table 1: Allotment of barley lines into treatments

\begin{tabular}{ccc}
\hline S.N. & Treatments & Barley lines \\
\hline 1 & 1 & B90k-014-1-1-2-0K \\
2 & 2 & Xveola-53 \\
3 & 3 & B90K-090-0K \\
4 & 4 & B86019-1K-2K-0K3 \\
5 & 5 & LG51/Xveola-5-77 \\
6 & 6 & Xveola-38 \\
7 & 7 & CHZ-NP-108-OY \\
8 & 8 & B86099-5-0K \\
9 & 9 & Xveola-15 \\
10 & 10 & B90k-024-1-1-2-0K \\
11 & 11 & NB-1003-37/1034 \\
12 & 12 & Bonus(std check) \\
13 & 13 & Local check \\
14 & 14 & CO11\#112-14 \\
\hline
\end{tabular}

Two to three harrowing with a disc harrow mounted on tractor followed by leveling and uniform grading was done for proper plant establishment and management. The field was divided into three blocks containing 14 plots each of size $3 * 2$ metre square. The seeds of different germplasm were line sown in each experimental unit by maintaining the row-row distance of $25 \mathrm{~cm}$. Irrigation was provided at two critical stages tillering and flowering. Fertilizer dose was applied at the ratio of 45:30:0 $\mathrm{kg}$ NPK/ha where the Nitrogen fertilizer was divided into 3 times among which half of the dose was applied as basal application and remaining half was divided equally again to be applied on tillering and flowering.Ten plants were sampled randomly 
for recording observation for each entry and 50 percentages completion out of the total plants was taken for days to heading, booting, anthesis and maturity. The different germplasm were harvested when most of the plants of particular germplasm turned yellow and dried up. When the spikes were well dried, threshing and cleaning was done followed by packing and storage. Data entry and processing was carried out using the Microsoft Office Excel 2010 software and means and standard deviation for all traits were compared. The testing of hypothesis and analysis of variance was calculated using R-software.

\section{RESULTS AND DISCUSSION}

\section{Phenological and growth attributing traits}

In our experiment there was high significant variation for days to booting, heading, anthesis and maturity among the tested barley germplasms.

A maximum day to booting was observed in the treatment Bonus (std. check) in 81 days and minimum days to booting was observed in the germplasm LG51/Xveola-577 in 68 days. CV value for days to booting was 2.81; LSD value among the tested germplasms was 3.39 and mean days to booting for the treatments was 72days.It was reported by(Vitrakoti et al., 2016), the days of booting for different barley genotypes ranged from 58-84 which is likely with our result. The mean days for booting were 69 days which is slightly lower than our result. The CV and LSD value were 3.47 and 4.77 respectively which were slightly higher than ours.

A maximum day to heading was observed in the treatment Bonus (std. check) in 81 days and minimum days to heading was observed in the germplasm LG51/Xveola-5-
77 in 72 days. CV value for days to heading was 2.4087; LSD value among the tested germplasms was 3.157078 and mean days to heading for the treatments was 78 days. (Vitrakoti et al., 2016), reported the days of heading for barley ranged from 71-96 days whereas our barley varieties were already headed till 81 days. This might be the result of the different varieties use in these two researches. The genetic characteristics of the different varieties might have contributed in this difference for days to heading.

A maximum day to anthesis was observed in the treatment Bonus (std. check) in 98 days and minimum days to anthesis was observed in the germplasm B90K-014-1-1-2$0 \mathrm{~K}$ in 79 days. CV value for days to anthesis was 1.694734; LSD value among the tested germplasms was 2.386527 and mean days to anthesis for the treatments was 84 days. Days of flowering ranged (92-117DAS) as reported by(Gupta et al., 2009) is slightly higher than this research which might have caused due to the difference in climate of Jumla and Chitwan or may be due to the use of naked barley germplasms in Mr. Gupta's research.

A maximum day to maturity was observed in the treatment CHZ-NP-108-OY in 111 days and minimum days to maturity was observed in the germplasm B86019-1K-2K0K3 in 97 days. CV value for days to maturity was 2.848386; LSD value among the tested germplasms was 5.045745 and mean days to maturity for the treatments was 106 days. Days of maturity ranged to $139-149$ as reported by in Khumaltar, Lalitpur(Gupta et al., 2009). This is very high than our result. This could be the result of temperature difference between the two cities or increased global warming over time.

Table 2: Phenological and growth attributing traits

\begin{tabular}{llllll}
\hline Genotype & $\begin{array}{l}\text { Days to Booting } \\
\text { (days) }\end{array}$ & $\begin{array}{l}\text { Days } \\
\text { Heading } \\
\text { (days) }\end{array}$ & $\begin{array}{l}\text { Days to } \\
\text { anthesis } \\
\text { (days) }\end{array}$ & $\begin{array}{l}\text { Days to } \\
\text { maturity } \\
\text { (days) }\end{array}$ \\
\hline B90k-014-1-1-2-0K & $69.7 \mathrm{c}$ & $73.7 \mathrm{ef}$ & $79.0 \mathrm{~h}$ & $100.0 \mathrm{de}$ \\
Xveola-53 & $70.3 \mathrm{c}$ & $77.7 \mathrm{~cd}$ & $80.3 \mathrm{fgh}$ & $102.7 \mathrm{~cd}$ \\
B90K-090-0K & $71.0 \mathrm{c}$ & $79.0 \mathrm{c}$ & $84.3 \mathrm{~cd}$ & $106.7 \mathrm{abc}$ \\
B86019-1K-2K-0K3 & $67.7 \mathrm{c}$ & $73.0 \mathrm{ef}$ & $81.7 \mathrm{efg}$ & $97.3 \mathrm{e}$ \\
LG51/Xveola-5-77 & $67.7 \mathrm{c}$ & $72.3 \mathrm{f}$ & $79.7 \mathrm{gh}$ & $100.0 \mathrm{de}$ \\
Xveola-38 & $70.3 \mathrm{c}$ & $75.7 \mathrm{de}$ & $81.0 \mathrm{efgh}$ & $107.3 \mathrm{abc}$ \\
CHZ-NP-108-OY & $70.3 \mathrm{c}$ & $80.3 \mathrm{c}$ & $85.7 \mathrm{c}$ & $111.0 \mathrm{a}$ \\
B86099-5-0K & $69.7 \mathrm{c}$ & $78.3 \mathrm{~cd}$ & $82.3 \mathrm{def}$ & $104.0 \mathrm{bcd}$ \\
Xveola-15 & $69.0 \mathrm{c}$ & $78.3 \mathrm{~cd}$ & $82.3 \mathrm{def}$ & $108.0 \mathrm{ab}$ \\
B90k-024-1-1-2-0K & $70.3 \mathrm{c}$ & $75.7 \mathrm{de}$ & $80.3 \mathrm{fgh}$ & $109.3 \mathrm{a}$ \\
\hline
\end{tabular}




\begin{tabular}{lllll}
\hline NB-1003-37/1034 & $71.0 \mathrm{c}$ & $78.3 \mathrm{~cd}$ & $85.7 \mathrm{c}$ & $109.3 \mathrm{a}$ \\
Bonus(std check) & $81.0 \mathrm{a}$ & $87.7 \mathrm{a}$ & $97.7 \mathrm{a}$ & $106.0 \mathrm{abc}$ \\
Local check & $76.3 \mathrm{~b}$ & $79.0 \mathrm{c}$ & $83.0 \mathrm{de}$ & $107.3 \mathrm{abc}$ \\
CO11\#112-14 & $79.7 \mathrm{ab}$ & $84.3 \mathrm{a}$ & $91.7 \mathrm{~b}$ & $108.7 \mathrm{ab}$ \\
\hline CV & $\mathbf{2 . 8}$ & $\mathbf{2 . 4 d e}$ & $\mathbf{1 . 7}$ & $\mathbf{4 . 3}$ \\
LSD & $\mathbf{3 . 4}$ & $\mathbf{3 . 2 b}$ & $\mathbf{2 . 4}$ & $\mathbf{0 . 2}$ \\
MEAN & $\mathbf{7 1 . 7}$ & $\mathbf{7 8 . 1}$ & $\mathbf{8 3 . 9}$ & $\mathbf{2 . 3}$ \\
F-test & $* * *$ & $* * *$ & $* * *$ & $* * *$
\end{tabular}

Note: Mean separated by DMRT and columns represented with the same letter (s) are non-significant at 5\% level of significance, $\mathrm{CV}=$ Coefficient of Variation, $\mathrm{LSD}=$ Least Significant Difference at 0.05 level of significance and $\mathrm{SD}=$ Standard Deviation

\section{Growth attributing traits}

In our experiment there was highly significant variation for tiller number among the tested barley germplasms. Maximum tiller number was exhibited by the treatment B90K-090-0K with 2.9 tillers and lowest tiller number was shown by the germplasm B86019-1K-2K-0K3 with 1.9 tillers. CV value for tiller number was 4.254319; LSD value among the tested germplasms was 0.1625237 and mean tiller number for the treatments was 2.3.(Gupta et al., 2009) reported the range for total tillers from 2.4-3.9 which is slightly higher than our result. This might be the result of better adaptability and thriving of barley in cool climatic condition of Jumla. The total tiller number affects the number of effective tillers which in higher number might favor the higher yield per plant.

In our experiment there was highly significant variation for effective tillers among the tested barley germplasms. Maximum effective tillers was exhibited by the treatment B90K-090-0K with 2.4 tillers and lowest effective tillers was shown by the germplasm B86099-5-0K with 1.6 tillers. CV value for effective tillers was 8.198947; LSD value among the tested germplasms was 0.2634164 and mean effective tillers for the treatments was 1.9. (Gupta et al., 2009), reported similar result for the effective tillers ranging from 1.9-7. The number of effective tillers is the ultimate characteristic causing variation in the yield.

In our experiment there was highly significant variation for flag leaf length among the tested barley germplasms. Maximum flag leaf length was shown by the treatment Xveola-38 with $12.9 \mathrm{~cm}$ and lowest flag leaf length was shown by the germplasm Local check with $6.3 \mathrm{~cm}$. CV value for flag leaf length was 4.594492; LSD value among the tested germplasms was 0.7685383 and mean flag leaf length for the treatments was $9.9 \mathrm{~cm}$. The flag leaf length of barley germplasm was ranged from $9.78 \mathrm{~cm}$ to $13.6 \mathrm{~cm}$ in the research conducted by(Joshi et al., 2020).

In our experiment there was highly significant variation for flag leaf width among the tested barley germplasms. Maximum flag leaf width was shown by the treatment CHZ-NP-108-OY with $0.9 \mathrm{~cm}$ and lowest flag leaf width was shown by the germplasm Bonus (std. check) with $0.4 \mathrm{~cm}$. CV value for flag leaf width was 4.515979; LSD value among the tested germplasms was 0.05383119 and mean flag leaf width for the treatments was $0.7 \mathrm{~cm}$. The flag leaf width of barley germplasm was ranged from 0.68 to $1.08 \mathrm{~cm}$ in the research conducted by(Joshi et al., 2020). It is slightly greater than our result. This might be due to the different germplasms used in the two studies.

Table 3: Growth attributing traits

\begin{tabular}{|c|c|c|c|c|}
\hline Genotype & Total tiller number & $\begin{array}{c}\text { Effective } \\
\text { Tillers }\end{array}$ & Flag leaf length $(\mathrm{cm})$ & $\begin{array}{c}\text { Flag leaf } \\
\text { width }(\mathrm{cm})\end{array}$ \\
\hline B90k-014-1-1-2-0K & $2.1 \mathrm{ef}$ & $1.9 \mathrm{cdef}$ & $10.4 \mathrm{e}$ & $0.7 \mathrm{de}$ \\
\hline Xveola-53 & $2.3 \mathrm{~cd}$ & $2.1 \mathrm{bcd}$ & 10.6de & $0.8 \mathrm{bc}$ \\
\hline B90K-090-0K & $2.9 \mathrm{a}$ & $2.4 \mathrm{a}$ & $10.7 \mathrm{bcde}$ & $0.7 \mathrm{e}$ \\
\hline B86019-1K-2K-0K3 & $1.9 \mathrm{~g}$ & $1.7 \mathrm{fg}$ & 10.6cde & $0.7 \mathrm{cde}$ \\
\hline LG51/Xveola-5-77 & $2.0 \mathrm{fg}$ & 1.8defg & $10.4 \mathrm{de}$ & $0.8 \mathrm{ab}$ \\
\hline Xveola-38 & $2.2 \mathrm{de}$ & $1.9 \mathrm{cdef}$ & $12.9 \mathrm{a}$ & $0.7 \mathrm{de}$ \\
\hline CHZ-NP-108-OY & $2.3 \mathrm{~cd}$ & $2.1 \mathrm{bc}$ & $11.1 \mathrm{bcd}$ & $0.9 \mathrm{a}$ \\
\hline B86099-5-0K & $2.1 \mathrm{ef}$ & $1.6 \mathrm{~g}$ & $11.4 \mathrm{~b}$ & $0.8 \mathrm{bcd}$ \\
\hline
\end{tabular}




\begin{tabular}{lllll}
\hline Xveola-15 & $2.1 \mathrm{ef}$ & $1.8 \mathrm{defg}$ & $8.7 \mathrm{f}$ & $0.7 \mathrm{e}$ \\
B90k-024-1-1-2-0K & $2.3 \mathrm{~cd}$ & $1.9 \mathrm{bcde}$ & $9.3 \mathrm{f}$ & $0.8 \mathrm{~b}$ \\
NB-1003-37/1034 & $2.4 \mathrm{bc}$ & $2.2 \mathrm{ab}$ & $11.4 \mathrm{bc}$ & $0.8 \mathrm{ab}$ \\
Bonus(std check) & $2.6 \mathrm{~b}$ & $1.7 \mathrm{efg}$ & $6.9 \mathrm{~g}$ & $0.4 \mathrm{~h}$ \\
Local check & $2.1 \mathrm{ef}$ & $1.7 \mathrm{fg}$ & $6.3 \mathrm{~g}$ & $0.5 \mathrm{~g}$ \\
CO11\#112-14 & $2.4 \mathrm{bc}$ & $2.0 \mathrm{bcd}$ & $8.7 \mathrm{f}$ & $0.6 \mathrm{f}$ \\
\hline CV & $\mathbf{4 . 3}$ & $\mathbf{8 . 2}$ & $\mathbf{4 . 6}$ & $\mathbf{4 . 5}$ \\
LSD & $\mathbf{0 . 2}$ & $\mathbf{0 . 3}$ & $\mathbf{0 . 8}$ & $\mathbf{0 . 1}$ \\
MEAN & $\mathbf{2 . 3}$ & $\mathbf{1 . 9}$ & $\mathbf{1 0 . 0}$ & $\mathbf{0 . 7}$ \\
F-test & $* * *$ & $* * *$ & $* * *$ & $* * *$
\end{tabular}

Note: Mean separated by DMRT and columns represented with the same letter (s) are non-significant at 5\% level of significance, $\mathrm{CV}=$ Coefficient of Variation, $\mathrm{LSD}=$ Least Significant Difference at 0.05 level of significance and $\mathrm{SD}=$ Standard Deviation

\section{Growth and yield attributing traits}

In our experiment there was moderate significant variation for flag leaf sheath length among the tested barley germplasms. Maximum flag leaf sheath length was shown by the treatment CHZ-NP-108-OY with $22.7 \mathrm{~cm}$ and lowest flag leaf sheath length was shown by the germplasm Bonus (std. check) with $18.1 \mathrm{~cm}$. CV value for flag leaf sheath length was 5.529546; LSD value among the tested germplasms was 1.905999 and mean flag leaf sheath length for the treatments was $20.5 \mathrm{~cm}$.

The flag leaf sheath stores photosynthetic products and transport to grains after heading which contributes yield up to $10-20 \%$ in case of rice(Gupta et al., 2009), reported similar result for flag leaf range from $14.02 \mathrm{~cm}$ to $21.78 \mathrm{~cm}$.

In our experiment there was high significant variation for plant height among the tested barley germplasms. Maximum plant height was shown by the treatment B90k$024-1-1-2-0 \mathrm{~K}$ with $106.7 \mathrm{~cm}$ and lowest plant height was shown by the germplasm Xveola- 15 with $82.3 \mathrm{~cm}$. CV value for plant height was 7.230024; LSD value among the tested germplasms was 11.48829 and mean plant height for the treatments was $94.7 \mathrm{~cm}$. This result is almost similar to the reported by(Amgai et al., 2011). Also study reported the plant height for barley ranged from $85.8 \mathrm{~cm}$ to $135.67 \mathrm{~cm}$. The variation in leaf appearance rate, leaf size and genetic makeup might have resulted in the variation of plant height.

In our experiment there was high significant variation for awn length among the tested barley germplasms. Maximum awn length was shown by the treatment B90K$090-0 \mathrm{~K}$ with $10.8 \mathrm{~cm}$ and lowest awn length was shown by the germplasm Xveola-38 with $8.9 \mathrm{~cm}$. CV value for awn length was 2.613249; LSD value among the tested germplasms was 0.4432893 and mean awn length for the treatments was $10.1 \mathrm{~cm}$.

Table 4: Growth and yield attributing traits

\begin{tabular}{|c|c|c|c|}
\hline Genotype & Sheath length $(\mathrm{cm})$ & $\begin{array}{l}\text { Plant height } \\
(\mathrm{cm})\end{array}$ & Awn length $(\mathrm{cm})$ \\
\hline B90k-014-1-1-2-0K & $20.9 \mathrm{abc}$ & 98.6abcd & $10.6 \mathrm{ab}$ \\
\hline Xveola-53 & $20.5 \mathrm{bcd}$ & 92.4def & $9.4 \mathrm{~d}$ \\
\hline B90K-090-0K & $21.0 \mathrm{abc}$ & 99.9abcd & $10.8 \mathrm{a}$ \\
\hline B86019-1K-2K-0K3 & 18.6de & 90.6def & $10.1 \mathrm{c}$ \\
\hline LG51/Xveola-5-77 & $21.8 \mathrm{ab}$ & $104.8 \mathrm{ab}$ & $10.8 \mathrm{a}$ \\
\hline Xveola-38 & $20.3 \mathrm{bcd}$ & $94.4 \mathrm{bcde}$ & $8.9 \mathrm{~d}$ \\
\hline CHZ-NP-108-OY & $22.7 \mathrm{a}$ & $104.4 \mathrm{abc}$ & $10.8 \mathrm{a}$ \\
\hline B86099-5-0K & $19.9 \mathrm{cde}$ & $82.4 \mathrm{f}$ & $9.9 \mathrm{c}$ \\
\hline Xveola-15 & $20.8 b c$ & $82.3 f$ & $10.1 \mathrm{c}$ \\
\hline B90k-024-1-1-2-0K & $20.9 \mathrm{abc}$ & $106.8 \mathrm{a}$ & $10.2 b c$ \\
\hline
\end{tabular}




\begin{tabular}{llll}
\hline NB-1003-37/1034 & $20.6 \mathrm{bc}$ & $96.2 \mathrm{abcd}$ & $9.9 \mathrm{c}$ \\
Bonus(std check) & $18.1 \mathrm{e}$ & $83.1 \mathrm{ef}$ & $10.7 \mathrm{a}$ \\
Local check & $19.7 \mathrm{cde}$ & $93.3 \mathrm{cdef}$ & $10.0 \mathrm{c}$ \\
CO11\#112-14 & $21.6 \mathrm{abc}$ & $96.1 \mathrm{abcd}$ & $9.1 \mathrm{~d}$ \\
CV & $\mathbf{5 . 5}$ & $\mathbf{7 . 2}$ & $\mathbf{2 . 6}$ \\
LSD & $\mathbf{1 . 9}$ & $\mathbf{1 1 . 5}$ & $\mathbf{0 . 4}$ \\
MEAN & $\mathbf{2 0 . 5}$ & $\mathbf{9 4 . 7}$ & $\mathbf{1 0 . 1}$ \\
F-test & $* *$ & $* * *$ & $* * *$
\end{tabular}

Note: Mean separated by DMRT and columns represented with the same letter (s) are non-significant at 5\% level of significance, $\mathrm{CV}=$ Coefficient of Variation, LSD $=$ Least Significant Difference at 0.05 level of significance and SD= Standard Deviation

\section{Yield attributing traits}

In our experiment there was high significant variation for spike length among the tested barley germplasms. Maximum spike length was shown by the treatment $\mathrm{CHZ}$ NP-108-OY with $7.7 \mathrm{~cm}$ and lowest spike length was shown by the germplasm Local check with $4.9 \mathrm{~cm}$. CV value for spike length was 3.798795; LSD value among the tested germplasms was 0.4019691 and mean spike length for the treatments was $6.3 \mathrm{~cm}$. Bista $(2015)$ reported that spike length was ranged from $5.41 \mathrm{~cm}$ to $7.03 \mathrm{~cm}$ which is almost similar with our result. Likewise, similar result was shown by (Eshghi \& Akhundova, 2009).

In our experiment there was non-significant variation for number of head per meter square among the tested barley germplasms. Maximum head per meter square was shown by the treatment B90K-090-0K with 251.3 heads and lowest head per meter square was shown by the germplasm B86099-5-0K with 179.7 heads. CV value for head per meter square was 20.49503; LSD value among the tested germplasms was 71.88255 and mean head per meter square for the treatments was 209 heads.

In our experiment there was high significant variation for grain per spike among the tested barley germplasms. Maximum grain per spike was shown by the treatment B90K-014-1-1-2-0K with 56.4 and lowest grain per spike was shown by the germplasm Bonus (std. check) with 26.9 grains. CV value for grain per spike was 11.79152 ; LSD value among the tested germplasms was 9.41914 and mean grain per spike for the treatments was 47.6 grains per spike.(Eshghi \& Akhundova, 2009) reported the number of grains per spike to be $17-59$ and $26-58$ respectively which is almost similar to our result.(Eshghi \& Akhundova, 2009), recorded the mean number of grains per spike to be 17 which is way lower than our result. This difference in the mean data might have occurred due to the climatic difference between Nepal and Rajasthan and also the use of different germplasms.

In our experiment there was high significant variation for grain yield per spike among the tested barley germplasms. Maximum grain yield per spike was shown by the treatment B90K-090-0K with $1.65 \mathrm{gm}$ per spike and lowest grain yield per spike was shown by the germplasm Bonus (std. check) with $0.73 \mathrm{gm}$ per spike. CV value for grain yield per spike was 23.38698; LSD value among the tested germplasms was 0.5099844 and mean grain yield per spike for the treatments was $1.3 \mathrm{gm}$ per spike. (Eshghi \& Akhundova, 2009), had a little higher result $(1.4 \mathrm{~cm}$ to $2.5 \mathrm{~cm}$ ) than that of ours for the grain yield per spike.

In our experiment there was high significant variation for seed length among the tested barley germplasms. Maximum seed length was shown by the treatment Xveola-38 with $11.2 \mathrm{~mm}$ and lowest seed length was shown by the germplasm B86099-5-0K with $9.8 \mathrm{~mm}$. CV value for seed length was 2.910947 ; LSD value among the tested germplasms was 0.508445 and mean seed length for the treatments was $10.4 \mathrm{~mm}$. This result is very higher than the seed length $6.9-9 \mathrm{~mm}$ as reported by(Eshghi \& Akhundova, 2009), which may have resulted due to the difference in number for grain per spike, genetic constitution, flag leaf area and chlorophyll content among different germplasms. 
Table 5: Yield attributing traits

\begin{tabular}{|c|c|c|c|c|c|}
\hline Genotype & $\begin{array}{l}\text { Spike } \\
\text { length } \\
\text { (cm) }\end{array}$ & $\begin{array}{l}\text { Number of } \\
\text { head/m2 }\end{array}$ & Grain per spike & $\begin{array}{l}\text { Grain yield per spike } \\
\text { (gm/spike) }\end{array}$ & $\begin{array}{l}\text { Seed } \\
\text { length(mm) }\end{array}$ \\
\hline B90k-014-1-1-2-0K & $6.2 \mathrm{c}$ & $204.7 \mathrm{a}$ & $56.4 \mathrm{a}$ & $1.5 \mathrm{ab}$ & $10.3 \mathrm{cde}$ \\
\hline Xveola-53 & $6.2 \mathrm{~cd}$ & $191.0 \mathrm{a}$ & $51.5 \mathrm{abc}$ & $1.3 \mathrm{abc}$ & $10.2 \mathrm{cde}$ \\
\hline B90K-090-0K & $5.5 \mathrm{ef}$ & $251.3 \mathrm{a}$ & 49.4abcd & $1.7 \mathrm{a}$ & $11.0 \mathrm{ab}$ \\
\hline B86019-1K-2K-0K3 & $6.0 \mathrm{~cd}$ & $193.7 \mathrm{a}$ & $44.5 \mathrm{~cd}$ & $0.9 \mathrm{~cd}$ & 10.0de \\
\hline LG51/Xveola-5-77 & $6.9 \mathrm{~b}$ & $209.0 \mathrm{a}$ & 49.9abcd & $1.5 \mathrm{ab}$ & $10.5 \mathrm{~cd}$ \\
\hline Xveola-38 & $5.4 \mathrm{f}$ & $201.7 \mathrm{a}$ & $51.5 \mathrm{abc}$ & $1.7 \mathrm{a}$ & $11.2 \mathrm{a}$ \\
\hline CHZ-NP-108-OY & $7.7 \mathrm{a}$ & $187.7 \mathrm{a}$ & $41.4 \mathrm{~d}$ & $1.2 \mathrm{abc}$ & $10.6 \mathrm{bc}$ \\
\hline B86099-5-0K & $5.8 \mathrm{de}$ & $179.7 \mathrm{a}$ & 47.1 abcd & $1.1 \mathrm{bcd}$ & $9.8 \mathrm{e}$ \\
\hline Xveola-15 & $6.1 \mathrm{~cd}$ & $244.7 \mathrm{a}$ & $51.5 \mathrm{abc}$ & $1.4 \mathrm{abc}$ & $10.6 \mathrm{bc}$ \\
\hline B90k-024-1-1-2-0K & $6.4 \mathrm{c}$ & $237.7 \mathrm{a}$ & $51.5 \mathrm{abc}$ & $1.5 \mathrm{abc}$ & $10.3 \mathrm{cde}$ \\
\hline NB-1003-37/1034 & $6.1 \mathrm{~cd}$ & $187.0 \mathrm{a}$ & $45.3 \mathrm{bcd}$ & $1.3 \mathrm{abc}$ & $10.2 \mathrm{cde}$ \\
\hline Bonus(std check) & $7.6 \mathrm{a}$ & $248.3 \mathrm{a}$ & $26.9 \mathrm{e}$ & $0.7 \mathrm{~d}$ & $9.9 \mathrm{e}$ \\
\hline Local check & $4.9 \mathrm{~g}$ & $206.3 \mathrm{a}$ & $45.1 \mathrm{bcd}$ & $1.4 \mathrm{abc}$ & $10.3 \mathrm{cde}$ \\
\hline CO11\#112-14 & $7.5 \mathrm{a}$ & $183.0 \mathrm{a}$ & $54.5 \mathrm{ab}$ & $1.1 \mathrm{bcd}$ & $10.6 \mathrm{bc}$ \\
\hline $\mathrm{CV}$ & 3.8 & 20.5 & 11.8 & 23.4 & 2.9 \\
\hline LSD & 0.4 & 71.9a & 9.4 & 0.5 & 0.5 \\
\hline MEAN & 6.3 & 209.0 & 47.6 & 1.3 & 10.4 \\
\hline F-test & $* * *$ & Ns & $* * *$ & $*$ & $* * *$ \\
\hline
\end{tabular}

Note: Mean separated by DMRT and columns represented with the same letter (s) are non-significant at 5\% level of significance, $\mathrm{CV}=$ Coefficient of Variation, $\mathrm{LSD}=$ Least Significant Difference at 0.05 level of significance and $\mathrm{SD}=$ Standard Deviation

\section{Yield and yield attributing traits}

In our experiment there was high significant variation for seed width among the tested barley germplasms. Maximum seed width was shown by the treatment $\mathrm{CHZ}$ NP-108-OY with $3.4 \mathrm{~mm}$ and lowest seed width was shown by the germplasm Xveola-53 with $2.7 \mathrm{~mm}$. CV value for seed width was 3.936254; LSD value among the tested germplasms was 0.2034439 and mean seed width for the treatments was $3 \mathrm{~mm}$. This result is almost similar to the result reported by (Bista, 2015), $2.17 \mathrm{~mm}$ to $3.06 \mathrm{~mm}$ and(Eshghi \& Akhundova, 2009) .

In our experiment there was high significant variation for thousand seed weight among the tested barley germplasms. Maximum thousand seed weight was exhibited by the treatment B90k-024-1-1-2-0K with 36.9gm and lowest thousand seed weight was shown by the germplasm Co11\#112-14 with 19.8gm. CV value for thousand seed weight was 2.263947; LSD value among the tested germplasms was 1.083716 and mean thousand seed weight for the treatments was 28.5gm. Gupta et al. (2009), reported the thousand seed weight to range from 36.446 gram which is greater than our result.(KARKOUR et al.,
2019), also recorded higher thousand seeds weight than ours which is $39 \mathrm{gm}$.

In our experiment there was high significant variation for grain yield per hectare among the tested barley germplasms. Maximum grain yield per hectare was exhibited by the treatment Xveola-38 with $1634.4 \mathrm{~kg} / \mathrm{ha}$ and lowest grain yield per hectare was shown by the germplasm Bonus (std. check) with $382.2 \mathrm{~kg} / \mathrm{ha}$. CV value for grain yield per ha was 24.66688; LSD value among the tested germplasms was 454.1431 and mean grain yield per ha for the treatments was $1096.984 \mathrm{~kg} / \mathrm{ha}$. Study reported the grain yield per hectare range from $1666.67 \mathrm{~kg} / \mathrm{ha}$ to $5141.67 \mathrm{~kg} / \mathrm{ha}$. This result is much greater than our result which might have resulted due to the differential performance and adaptability of the respective germplasms in the climatic condition of Khumaltar and Chitwan respectively. 
Table 6: Yield and yield attributing traits

\begin{tabular}{|c|c|c|c|c|}
\hline Genotype & Seed width(mm) & Thousand seed weight (gm) & Grain yield per plot (kg/plot) & $\begin{array}{l}\text { Grain yield per hectare } \\
(\mathrm{kg} / \mathrm{ha})\end{array}$ \\
\hline B90k-014-1-1-2-0K & $2.9 \mathrm{~cd}$ & $31.3 \mathrm{bc}$ & $0.7 \mathrm{abc}$ & 1221.1abc \\
\hline Xveola-53 & $2.7 \mathrm{~d}$ & $25.8 \mathrm{e}$ & $0.5 \mathrm{def}$ & 753.3def \\
\hline B90K-090-0K & $3.1 \mathrm{bc}$ & $31.4 \mathrm{bc}$ & $0.7 \mathrm{bcd}$ & $1161.1 \mathrm{bcd}$ \\
\hline B86019-1K-2K-0K3 & $2.9 \mathrm{~cd}$ & $21.5 f$ & $0.7 \mathrm{bcd}$ & $1121.1 \mathrm{bcd}$ \\
\hline LG51/Xveola-5-77 & $3.2 \mathrm{ab}$ & $31.7 b$ & $0.7 \mathrm{bcd}$ & $1115.6 \mathrm{bcd}$ \\
\hline Xveola-38 & $3.1 \mathrm{bc}$ & $36.2 \mathrm{a}$ & $0.9 \mathrm{a}$ & $1634.4 \mathrm{a}$ \\
\hline CHZ-NP-108-OY & $3.4 \mathrm{a}$ & $30.6 \mathrm{bc}$ & $0.8 \mathrm{abc}$ & $1275.6 \mathrm{abc}$ \\
\hline B86099-5-0K & $3.0 \mathrm{bc}$ & $24.7 \mathrm{e}$ & $0.4 \mathrm{ef}$ & 646.7ef \\
\hline Xveola-15 & $3.1 \mathrm{~b}$ & $25.0 \mathrm{e}$ & $0.8 \mathrm{ab}$ & $1388.9 \mathrm{ab}$ \\
\hline B90k-024-1-1-2-0K & $3.2 \mathrm{bc}$ & $36.9 \mathrm{a}$ & $0.8 \mathrm{abc}$ & $1352.2 \mathrm{abc}$ \\
\hline NB-1003-37/1034 & $3.1 \mathrm{bc}$ & $28.7 \mathrm{~d}$ & $0.8 \mathrm{abc}$ & $1302.2 \mathrm{abc}$ \\
\hline Bonus(std check) & $3.1 \mathrm{bc}$ & $25.3 \mathrm{e}$ & $0.2 \mathrm{f}$ & $382.2 \mathrm{f}$ \\
\hline Local check & $3.1 \mathrm{bc}$ & $30.4 \mathrm{c}$ & $0.6 \mathrm{cde}$ & $933.3 \mathrm{cde}$ \\
\hline CO11\#112-14 & $3.1 \mathrm{bc}$ & $19.8 \mathrm{~g}$ & $0.6 \mathrm{bcde}$ & 1070.0bcde \\
\hline $\mathbf{C V}$ & 3.9 & 2.3 & 24.7 & 24.7 \\
\hline LSD & 0.2 & 1.1 & 0.3 & 454.1 \\
\hline MEAN & 3.1 & 28.5 & 0.7 & 1097.0 \\
\hline F-test & $* * *$ & $* * *$ & $* * *$ & $* * *$ \\
\hline
\end{tabular}

Note: Mean separated by DMRT and columns represented with the same letter (s) are non-significant at 5\% level of significance, CV= Coefficient of Variation, LSD= Least Significant Difference at 0.05 level of significance and $\mathrm{SD}=$ Standard Deviation 
Table 7: Correlation of quantitative traits

\begin{tabular}{|c|c|c|c|c|c|c|c|c|c|c|c|c|c|c|c|c|c|c|}
\hline & DTB & DTH & DTA & DM & tn & Et & Fl & Fw & Sl & PH & Al & spl & GPS & GYS & sel & sw & tswt & GY \\
\hline DTB & & $\begin{array}{l}0.83 \\
* * *\end{array}$ & $0.84 * * *$ & -0.09 & -0.11 & -0.17 & $-0.44 * * *$ & $-0.37 * *$ & 0.13 & -0.2 & 0.15 & 0.12 & $0.43 * * *$ & $-0.31 *$ & -0.01 & -0.18 & -0.1 & -0.24 \\
\hline DTH & & & $0.78^{* * *}$ & -0.09 & -0.06 & -0.12 & -0.3 & -0.25 & 0.07 & -0.3 & 0.05 & 0.06 & $0.42 * * *$ & $-0.34 * *$ & 0.05 & -0.12 & -0.17 & -0.13 \\
\hline DTA & & & & -0.1 & -0.06 & -0.12 & $-0.39 * *$ & $-0.44 * * *$ & -0.09 & $-0.4 * * *$ & 0.01 & 0.25 & 0.46 & -0.46 & $\begin{array}{l}-0.1 \\
\end{array}$ & -0.23 & -0.24 & -0.32 \\
\hline DTM & & & & & 0.1 & -0.02 & 0.03 & -0.04 & 0.23 & 0.13 & -0.18 & $\begin{array}{l}0.32 \\
* *\end{array}$ & $0.06 * * *$ & $0.13 * * *$ & 0.03 & 0.24 & 0.24 & 0.07 ** \\
\hline et & & & & & & & 0.21 & 0.21 & 0.11 & $0.44 * * *$ & 0.11 & 0.1 & 0.25 & 0.27 & 0.02 & -0.07 & 0.22 & 0.09 \\
\hline $\mathrm{Fl}$ & & & & & & & & $0.46 * * *$ & 0.26 & $0.35 * *$ & $\begin{array}{l}- \\
0.32 *\end{array}$ & 0.08 & 0.2 & $0.33 * *$ & 0.2 & 0 & 0.22 & 0.23 \\
\hline $\mathrm{Fw}$ & & & & & & & & & $0.44 * * *$ & $0.41 * * *$ & -0.07 & 0.04 & $0.3 *$ & 0.28 & -0.08 & -0.01 & 0.18 & $\begin{array}{l}0.41 \\
* * *\end{array}$ \\
\hline Sl & & & & & & & & & & $0.5 * * *$ & -0.06 & 0.22 & $0.31 *$ & $0.39 * * *$ & 0.2 & 0.16 & $0.31 *$ & 0.18 \\
\hline $\mathrm{Al}$ & & & & & & & & & & & & $\begin{array}{l}- \\
0.04\end{array}$ & 0.19 & -0.17 & 0 & 0.13 & -0.14 & 0.1 \\
\hline $\mathrm{spl}$ & & & & & & & & & & & & & 0.21 & -0.26 & 0.04 & 0.04 & -0.1 & -0.28 \\
\hline GPS & & & & & & & & & & & & & & $0.73 * * *$ & 0.17 & -0.07 & 0.26 & 0.23 \\
\hline GYS & & & & & & & & & & & & & & & $0.32 * *$ & 0.08 & $0.78 * * *$ & 0.39 ** \\
\hline Sel & & & & & & & & & & & & & & & & 0.2 & 0.24 & 0.1 \\
\hline $\mathrm{Sw}$ & & & & & & & & & & & & & & & & & 0.15 & -0.15 \\
\hline Tswt & & & & & & & & & & & & & & & & & & 0.19 \\
\hline GY & & & & & & & & & & & & & & & & & & \\
\hline
\end{tabular}

DTB- Day to booting, DTH- Days to heading, DTA- Days to anthesis, DTM- Days to maturity, tn- Tiller numbers, et- number of effective tillers, fl- Flag leaf length, fwFlag leaf width, sl- Flag leaf sheath length, PH- Plant height, al- Awn length, spl- Spike length, GPS- Grains per spike, GYS- Grain yield per spike, sel- Seed length, swSeed width, tswt- Thousand seed wight and GY- Grain yield per hectare, ***p=0.001>, **p=0.01-0.001, * $\mathrm{p}=0.04-0.01$. 
Correlation between all quantitative traits was analyzed. The days to booting was highly significant and positively correlated with days to heading $(0.83 * * *)$ and days to booting $(0.84 * * *)$. Days to maturity was non-significant and negatively correlated with days to booting $(-0.09 \mathrm{~ns})$, days to heading (-0.09ns) and days to anthesis (-0.1ns).

Tiller number and effective tillers were highly significant and positively associated with each other $(0.87 * * *)$. Plant top became tremendous and negatively correlated with days to heading $\left(-0.3^{*}\right)$ while non-sizable and negatively correlated with days to booting (-zero.2ns) and days to maturity $(-0.04 \mathrm{~ns})$. Plant top changed into significant and undoubtedly correlated with tiller wide variety (zero.three*), notably good sized and positively correlated with powerful tiller $\left(0.44^{* * *}\right)$, flag leaf width (zero.forty one***) while reasonably good sized and positively correlated with flag leaf duration (zero.35**).Flag leaf length and flag leaf width were highly significant and positively correlated $\left(0.46^{* * *}\right)$ with each other. Grains per spike and grain yield per spike were highly significant and strong positively associated $(0.73 * * *)$ with each other.

Thousand seed weight was highly significant and positively correlated with plant height $\left(0.45^{* * *}\right)$ and grain yield per spike $\left(0.78^{* * *}\right)$. Thousand seed weight and grain yield were non-significant and positively correlated $(0.19 \mathrm{~ns})$ with each other.

Grain yield per hectare was moderately significant and positively correlated with days to maturity $(0.07 * *)$, plant height $\left(0.45^{* *}\right)$ and grain yield per spike $\left(0.1^{* *}\right)$ whereas highly significant and positively correlated with flag leaf width $(0.41 * * *)$. Grain yield per hectare was nonsignificant and negatively correlated with days to booting $(-0.24 n s)$, days to heading $(-0.13 n s)$, days to anthesis ($0.32)$, tiller number $(-0.01 \mathrm{~ns})$, spike length $(-0.28 \mathrm{~ns})$ and seed width $(-0.15 \mathrm{~ns})$.

Characters like flag leaf width and tiller numbers, seed length and awn length, seed width and flag leaf length are not associated (0.00) with each other.

In the article published by(Vitrakoti et al., 2016),grain yield in keeping with hectare had advantageous and noticeably massive end resultwith thousand seed weight (which was positive but non-significant in our result), positive and significant correlation with spike length (which was negative and non-significant in our result) whereas grain yield per hectare showed negative highly significant correlation with days to flowering. Although there exists positive relationship between yield and the other components, the negative correlation between some of them cannot make a useful choice for all as a factor in increasing the yield (Kannenberg 1976).There was nonsignificant positive correlation between plant height and thousand seed weight (Drikvand 2011), which was positive and highly significant in our result. Thousand grain weights had positive high significant association with grain yield per hectare (which was positive and non-significant in our result) followed by spike length (which was negative and non-significant in our result) and negative high significant association with days to flowering followed by days to booting and days to heading (similar to our result).

Highly significant favorable correlation among yield attributing tendencies suggests that, the unit increment in one of the trait will motive a unit increment inside the every other relatedtraits, which in turn will lead to increase in the grain yield. Hence, these traits could be pointed and noted for the improvement of grain yield by focusing on the associated traits (Vitrakoti 2016).

\section{CONCLUSION}

Analysis showed non-significant for the number of heads per meter square and significant variation for all other traits. The analysis indicated that highly significant difference existed for most of the quantitative data which implies that there exists vast diversity among the breeding lines for different traits.

Plant height turned into considerable and undoubtedly correlated with tiller variety, incredibly significant and positively correlated with powerful tiller, flag leaf width while substantially and positively correlated with flag leaf length. Grains consistent with spike and grain yield in step with spike had been pretty widespread and sturdy undoubtedly associated with every different. Grain yield per hectare became drastically and undoubtedly correlated with days to adulthood, plant height and grain yield in line with spike whereas exceptionally giant and definitely correlated with flag leaf width. Xveola-38 performed better for yield attributing traits whereas B86019-1K-2K0K3 showed better phenotypic characters and adaptability. These lines of barley have the possibilities and potentials for further study and research in Rampur, Chitwan. Early maturing lines like CHZ-NP-108-OY, B90k-024-1-1-20K, NB-1003-37/1034 and CO11\#112-14 which have short crop period can be suggested for cultivation in drought prone areas as they can escape drought period. B86019-1K-2K-0K3 showed better adaptability and results for phenotypic characters which can contribute for the crop improvement and plant breeding program. Likewise, Xveola-38 performed best for the yield and yield attributing traits, so this variety could have the potentiality to be released for commercial cultivation in Rampur, Chitwan which can be justified after further study and research. 


\section{ACKNOWLEDGEMENT}

I am indebted to all the love, courage, support and encouragement shown by people around me during the whole period of my research and thesis. All this has given me strength to do my work with more enthusiasm for its successful completion. I am very grateful to each and every individual that made this research and thesis process successful and educational in every way possible. This research has been a great opportunity for me to increase my knowledge and experience. I am also very grateful to all the faculty members and staffs of NPI for their continuous support during my entire student life in NPI. My heart is filled with gratitude for Mr. Dhruba Regmi sir, who provided me an opportunity to carry out the research inside the Seed Production Unit, Rampur and also managed me the seeds to the fourteen germplasms of barley.

\section{AUTHORS DECLARATION}

The authors declare that there is no any conflict of interest. Mr. Anup Adhikari designed the layout and work plan for this research while Pabitra Ale, Jigyasha Gautam, Babita Dhungana and Aakash Adhikari performed cultivation practices, recorded the data, performed statistical analysis of data, revised the first draft minutely and elaborated the final manuscript for publication. All the authors have read the manuscript and approve the final version.

\section{REFERENCES}

[1] Amgai, R. B., Pantha, S., Chhetri, T. B., \& Mudwari, A. (2011). Nepalese barley: Variation in agro-morphology characteristics. Proceedings of 28th National Winter Crops Workshop, Held On, 9-10.

[2] Baniya, B. K. (1989). Present status of barley improvement in Nepal. A Workshop/Training on Barley February, 24.

[3] Baniya, B. K., Dongol, D. M. S., \& Riley, K. W. (1997). Characterization of Nepalese barley germplasm. Barley and Wheat Newsletter.

[4] Eshghi, R., \& Akhundova, E. (2009). Genetic diversity of the monomeric prolamins and hordein in hulless barley genotypes and their relation with agronomical traits. African Journal of Biotechnology, 8(9).

[5] Gupta, S. R., Upadhyay, M. P., \& Shah, U. S. (2009). Agromorphological variability study of barley (Hordeum vulgare L.) landraces in Jumla, Nepal. Nepal Agriculture Research Journal, 9, 1-11.

[6] Joshi, B. K., Gorkhali, N. A., Pradhan, N., Ghimire, K. H., Gotame, T. P., KC, P., Mainali, R. P., Karkee, A., \& Paneru, R. B. (2020). Agrobiodiversity and its Conservation in Nepal. Journal of Nepal Agricultural Research Council, 6(March), 14-33. https://doi.org/10.3126/jnarc.v6i0.28111
[7] KARKOUR, L., FENNI, M., RAMLA, D., GAAD, D., \& BENBELKACEM, A. (2019). Evaluation of agronomic performances of rainfed barley double-haploids (DHs) lines under semi-arid conditions. Biodiversitas Journal of Biological Diversity, 20(5).

[8] Vitrakoti, D., Aryal, S., Rasaily, S., Ojha, B. R., Kharel, R., \& Sapkota, M. (2016). Study on genotypic response and correlation analysis of the yield and yield attributing traits of different barley (Hordeum vulgare) genotypes. International Journal of Applied Sciences and Biotechnology, 4(4), 529536.

[9] Yadav, R. K., Gautam, S., Palikhey, E., Joshi, B. K., Ghimire, K. H., Gurung, R., Adhikari, A. R., Pudasaini, N., \& Dhakal, R. (2018). Agro-morphological diversity of Nepalese naked barley landraces. Agriculture \& Food Security, 7(1), 1-12. 